\title{
WHEN HISTORY NO LONGER SUFFICE: TOWARDS UNIFORM RULES FOR ARMED CONFLICTS
}

\author{
Pieter Brits \\ Stellenbosch University
}

\begin{abstract}
The key instruments of International Humanitarian Law (IHL), the 1949 Geneva Conventions and the Additional Protocols of 1977, divide armed conflict into two legal categories: international armed conflicts (IACs) or non-international armed conflicts (NIACs). While international armed conflicts are regulated by the whole range of Geneva Conventions, there is only one single article, Common Article 3 to the Geneva Conventions that provides for non-international armed conflicts. The same applies to the Additional Protocols to the Geneva Conventions of 1977. This is concerning, as the bulk of conflicts since 1945 have been noninternational in nature. The end of the $20^{\text {th }}$ century saw an increase in internationalised armed conflicts: conflicts that may have started as internal conflicts but due to third-state intervention or the scope and magnitude of the conflict, have become something that transcends categorisation as internal armed conflicts. These conflicts can either remain NIACs or become IACs. Depending on the nature of the parties involved, one could even have a situation where the rules to both types of conflicts apply simultaneously with dire legal effects for the parties involved. The events of 11 September 2001 and the so-called 'war on terror' brought transnational armed conflicts to the foreground: cross-border conflicts that often fall outside the scope of the classic IAC and also fail to meet the requirement for NIACs that requires the conflict to take place "within the territory of one of the High Contracting Parties". After examining the historical background leading up to the classification of armed

Scientia Militaria, South African Journal of Military Studies, Vol 45, No. 2, 2017, pp. 64-80. doi : $10.5787 / 45-2-1210$ conflicts as either IAC or NIAC, the article reflects on recent developments and asks whether the time has not arrived to do away with the Geneva Convention straightjacket for purposes of determining rules applicable to a particular conflict.
\end{abstract}




\section{Introduction}

Until 1949, International Humanitarian Law (IHL) primarily consisted of common law rules accompanied by a very limited number of treaties. ${ }^{1}$ The four Geneva Conventions ${ }^{2}$ that were adopted in the aftermath of World War II started a codification process that is still ongoing today. ${ }^{3}$ The 1949 Geneva Conventions and the two Additional Protocols that followed in 1977, divide armed conflict into two legal categories: international armed conflicts (IACs) and non-international armed conflicts (NIACs). ${ }^{4}$ Whilst IACs are subject to the whole range of the Geneva Conventions, there is only one single article, Common Article 3 to the Geneva Conventions that provides for NIACs. The same applies to the Additional Protocols to the Geneva Conventions of 1977. Whilst Protocol I on the protection of victims of IACs consists of 102 Articles, Protocol II on the protection of victims of NIACs, are much more limited and consists of only 28 articles. The second key event of the period after World War II was the emergence of International Human Rights Law (IHRL), starting with the Universal Declaration of Human rights in 1948, which would have a significant influence on the future development of IHL, especially with regard to the treatment of NIACs. ${ }^{5}$

\section{Common Article 2}

Defining its field of application, the Geneva Conventions draw a clear distinction between IACs and NIACs. In terms of Article 2, common to the four Geneva Conventions, the Conventions apply "to all cases of declared war or of any other armed conflict which may arise between two or more of the High Contracting Parties", thus to international armed conflict between states.

\footnotetext{
${ }^{1}$ The first IHL convention, the Convention on the Amelioration of the Condition of Wounded Armies in the Field, was adopted in 1864. This was followed by the Hague Conventions of 1899 and 1907, which introduced limitations on the force used by states and contained many provisions of humanitarian nature. Kretzmer, D. 'Rethinking the Application of IHL in Non-International Armed Conflicts' (2009) 42 Israel Law Review at 12.

${ }^{2}$ First Convention for the Amelioration of the Condition of the Wounded and Sick in Armed Forces in the Field. Second Convention for the Amelioration of the Condition of Wounded, Sick and Shipwrecked Members of Armed Forces at Sea. Third Convention relative to the Treatment of Prisoners of War. Fourth Convention relative to the Protection of Civilian Persons in the Time of War.

${ }^{3}$ For a complete list of IHL treaties, according to date or topic, see the ICRC website at https://www.icrc.org/appli/ihl/ihl.nsf/vwTreatiesByTopics.xsp.

${ }^{4}$ Art. 2 common to the four Geneva Conventions.

${ }^{5}$ Kretzmer op cit 9.
} 
In 1948, the International Committee of the Red Cross (ICRC) submitted a proposal in Geneva that the four Conventions be expanded in their entirety to "all cases of armed conflict which are not of an international character, especially cases of civil war, colonial conflicts, or wars of religion, which may occur in the territory of one or more of the High Contracting Parties". 6

The proposal was based on the premises that internal conflicts are no less serious or inhumane than inter-state conflicts. ${ }^{7}$ Three groups emerged:

- $\quad$ those states that supported the proposal ${ }^{8}$

- those that rejected the proposal, because according to them, it would undermine state sovereignty and national security $;^{9}$ and finally

- $\quad$ an intermediate group that wanted the conventions to be restricted to apply only when certain objective conditions are met, for instance where the insurgents constituted an organised group in control of part of the territory and were prepared to respect international norms. ${ }^{10}$

In the end, the proposal was rejected by most states and a compromise was reached to have one single provision to provide for NIACs: Article 3 common to the four Geneva Conventions.

\section{Common Article 3}

While not being the extension the ICRC had hoped for, Common Article 3 is still regarded as groundbreaking, as it was the first lex scripta to cover situations of NIAC occurring in the territory of one of the contracting state parties. ${ }^{11}$ Although Article 3 has been called "mini-Convention" or a "convention within the

${ }^{6}$ Stewart, JG 'Towards a Single definition of Armed Conflict in International Humanitarian Law: A Critique of Internationalized Armed Conflict' (2003) 85 International Review of the Red Cross at 313, referring to Pictet, J (ed) Commentaries on the Geneva Conventions of 12 August 1949, Vol III: Relative to the Treatment of Prisoners of War (ICRC 1960) at 31. Full text available at https://www.loc.gov/rr/frd/Military_Law/pdf/GC_1949-III.pdf.

${ }^{7}$ Cassese, A The Human Dimension of International Law: Selected Papers (Oxford University Press 2008) at 115.

${ }^{8}$ This group included Western states such as Norway and Denmark, Third World states such as Mexico and some socialist states such as the Soviet Union, Hungary, Romania, Bulgaria and Byelorussia; ibid 116.

${ }^{9}$ This group included Burma, the United Kingdom, Greece and Australia; ibid. Cassese, p. 116.

${ }^{10}$ This group included the Western states France, Spain, Italy and the USA as well as Nationalist China; ibid 116. For a complete discussion, see Pictet op cit 32-4.

${ }^{11}$ Schmitt, M 'Classification of Cyber Conflict' (2012) 17 (2) Journal of Conflict and Security Law at 249. 
Conventions", ${ }^{12}$ it extends only the most basic rules of humanitarian protection ${ }^{13}$ to NIACs. Article 3 further requires humane and non-discriminatory treatment for all persons in enemy hands, including members of the armed forces who had laid down their arms or who had become hors de combat through sickness, wounds or detention. It specifically prohibits murder; mutilation; torture; cruel, humiliating and degrading treatment; the taking of hostages and unfair trials. In addition, it provides for the collection and treatment of the sick and wounded.

Article 3 further provides that an impartial humanitarian, body such as the ICRC, "may offer its services to the parties to the conflict". While some regard this as a built-in guarantee mechanism, ${ }^{14}$ the mere fact that humanitarian organisations are now legally entitled to offer their services does not compel conflicting parties to accept the offer. Parties may still reject the offer, but they can no longer resent the fact that the organisation impartially tried to come to the aid of the victims of the conflict. ${ }^{15}$ However, in practice, offers by the ICRC are seldom rejected. State parties will rather define the limits of service in such a way that it promotes the appearance of compliance, or if rejected, argue that the particular matter is only an internal disturbance falling under the jurisdiction of the state. ${ }^{16}$

Parties are encouraged to conclude special agreements to bring into force all or parts of the other provisions of the Geneva Conventions. To allay fears of de jure governments that the conclusion of such agreements may increase the authority of the non-state actors that revolted against it, by constituting implicit recognition of its existence and belligerent status, Common Article 3 concludes with an express provision that the application of any part of it shall not affect the legal status of any of the parties to the conflict. Without this provision, Article 3 would probably never have been adopted. ${ }^{17}$

${ }^{12}$ ICRC, (2010) "The Geneva Conventions of 1949 and their Additional Protocols", Overview, pp. 1-3. Available at https://www.icrc.org/eng/war-and-law/treaties-customarylaw/geneva-conventions/overview-geneva-conventions.htm accessed 31 August 2016 at 3 . According to Cassese op cit 117 it was the Soviet delegate Morozov who, with a hint of criticism, defined common Article 3 as "a convention in miniature".

${ }^{13}$ Cassese op cit 117 describes these principles as "principles of human rights", while Pictet op cit 35 uses the term "rules of humanity".

${ }^{14}$ Cassese op cit 119.

${ }^{15}$ ICRC Commentary on the Second Geneva Convention (1960) at 37.

${ }^{16}$ Ghandi, M 'Common Article 3 of Geneva Conventions, 1949 in the Era of International Criminal Tribunals' (2001) 1 Indian Society of International Law (ISIL) Year Book of International Humanitarian and Refugee Law at 2.

${ }^{17}$ Pictet op cit 43; Junod, S ‘Additional Protocol II: History and Scope’ (1983) 33 The American University Law Review at 30. 


\section{Definition of NIAC under Common Article 3}

Given Common Article 2, it is widely accepted that Article 3 applies to armed conflicts between a state and a non-state armed group or groups, or between such groups themselves. ${ }^{18}$

With regard to its field of application, Article 3 refers to "armed conflict not of an international character in the territory of the High Contracting Parties". The term 'armed conflict' is not defined in the Conventions. However, it was evident from the outset that Article 3 intended to apply to conflicts "with armed forces on either side engaged in hostilities", thus serious conflicts, excluding mere rebellions or temporary internal disturbances. ${ }^{19}$ Since the four Geneva Conventions have been universally ratified, ${ }^{20}$ the opinion has been expressed that the requirement that the conflict must take place "in the territory of one of the High Contracting Parties" lost its importance since the conflict cannot take place but in the territory of one of the parties. $^{21}$ In the words of Zegfeld, "internal conflicts are distinguished from international armed conflicts by the parties involved rather than by the territorial scope of the conflict". 22

At least two criteria have to be assessed before a conflict can be classified as an NIAC within the ambit of Common Article 3: the intensity of the conflict and the organisation of the parties. ${ }^{23}$ Both are questions of fact. Factors to consider when assessing the intensity of the conflict include -

- $\quad$ the seriousness of attacks;

- whether there has been an increase in armed clashes;

- $\quad$ the spread of clashes over a territory and over a period of time;

${ }^{18}$ Pejic, J 'The Protective Scope of Common Article 3: More than Meets the Eye' (2011) 93 (881) International Review of the Red Cross at 191; Schmitt op cit 249; Ghandi op cit 2. Also see ICRC 'How is the Term "Armed Conflict" Defined in International Humanitarian Law?', opinion paper (March 2008) at 3, available at https://www.icrc.org/eng/assets/files/other/opinion-paper-armed-conflict.pdf.

${ }^{19}$ Pictet op cit 37.

${ }^{20}$ Spoerri, P 'The Geneva Conventions of 1949: Origins and Current Significance, 12-08-2009 Statement', address delivered at Ceremony to celebrate the 60th anniversary of the Geneva Conventions (2009) at 6, available at https://www.icrc.org/eng/resources/documents/statement/geneva- conventionsstatement-120809.htm.

${ }^{21}$ ICRC (2008) op cit 3. While this may hold true with regard to the Conventions, the same cannot be said with regard to the Protocols to the Geneva Conventions.

${ }^{22}$ Zegveld, L Accountability of Armed Opposition Groups in International Law (Cambridge University Press 2002) at 136.

${ }^{23}$ ICTY, The Prosecutor v DuškoTadić, Judgment, IT-94-1-T, 7 May 1997, para. 562; also see ICTY, The Prosecutor v FatmirLimaj, Judgment, IT-03-66-T, 30 November 2005, para. 84 that approved and followed the criterion laid down by the Tadic Judgment. 
- $\quad$ increases in the number of government forces;

- the mobilisation and distribution of weapons among both parties to the conflict;

- whether the conflict has attracted the attention of the United Nations Security Council; and

- whether any resolutions on the matter have been passed. ${ }^{24}$

For the purposes of Article 3, the International Criminal Tribunal for the Former Yugoslavia (ICTY) deemed an NIAC to exist "whenever there is ... protracted armed violence between governmental authorities and organized armed groups or between such groups within a State". ${ }^{25}$ This is consistent with the definition contained in the Rome Statute of the International Criminal Court. ${ }^{26}$ The second criterion requires non-governmental groups involved in the conflict to be considered 'parties to the conflict', meaning that they should meet a certain level of organisation. Factors to consider specifically in the case of non-state armed groups include as a minimum the ability of the leadership to exercise some control over its members so that the basic obligations of Common Article 3 may be implemented. ${ }^{27}$ In the wording of the Tadic Judgment, these criteria are used "solely for the purpose ... of distinguishing an armed conflict from banditry, unorganized and short-lived insurrections, or terrorist activities, which are not subject to international humanitarian law".28

Article 3 will automatically come into operation as soon as it is clear that there is a de facto situation of armed conflict. ${ }^{29}$ Its application will continue beyond the cessation of hostilities until a peaceful settlement is achieved, in the whole territory under the control of a party, whether or not actual combat takes place there. ${ }^{30}$ Article 3 expressly states, "each party to the conflict shall be bound", thereby binding both state and non-state parties, even though the last group have not been signatories to the Conventions. They are bound because Common Article 3 forms

${ }^{24}$ ICTY, The Prosecutor v FatmirLimaj op cit para. 90.

${ }^{25}$ ICTY, The Prosecutor $v$ DuškoTadić, Decision on the Defence Motion for the Interlocutory Appeal on Jurisdiction, IT-94-1-A, 2 October 1995, para. 70. The test has since been consistently followed by the ICTY; see The Prosecutor $v$ FatmirLimaj op cit para. 84.

${ }^{26}$ Art 8(2)(f) of the Rome Statute of the International Criminal Court, 17 July 1998; the Statute entered into force on 1 July 2002; also see Pejic op cit 192.

${ }^{27}$ ICTY, The Prosecutor v Boškoski and Tarčulovski, Case No. ICTY-IT-04-82-T, Judgment (Trial Chamber), 10 June 2008, para. 196.

${ }^{28}$ ICTY, The Prosecutor v DuškoTadić, Judgment op cit para. 562.

${ }^{29}$ Junod op cit 30. For a more detailed assessment, see Grignon, J 'The Beginning of Application of International Humanitarian Law: A Discussion of a Few Challenges' (2014) 96 International Review of the Red Cross at 139-62.

${ }^{30}$ ICTY, The Prosecutor v DuškoTadić, Jurisdiction Decision op cit para. 70. 
part of customary international law. ${ }^{31}$ From the wording, it is clear that Article 3 intends to be humanitarian in nature. It never intended to interfere with the right of a de jure government to suppress a rebellion, in particular with the right of such government to prosecute, try and sentence perpetrators according to its own laws. In the same vein, Article 3 never uses the term 'combatant', preferring to use the illustrious "persons taking no active part in hostilities". ${ }^{32}$ Although well intended, the very creation of two different types of armed conflict had important legal consequences. For the belligerents, the classification is crucial. The moment conflict is classified as an NIAC it means that they are not entitled to claim legitimate combatant or prisoner of war status. ${ }^{33}$ The same applies for the victims, as the victims of NIACs enjoy fewer protections under IHL than those of international conflicts. ${ }^{34}$

Despite wide mentioning, Article 3 does not enjoy equal support in practice. States where civil war broke out, preferred to maintain that the disturbance was sporadic, whilst the rebels, who knew that they were going to be punished, had little interest in applying Article 3. Even when states, were compelled to admit the existence of an IAC under Article 3, they still carefully avoided to respect all the provisions of Article $3 .{ }^{35}$ Given that NIACs became the rule rather than the exception, to the extent that about $80 \%$ of the victims since 1945 had been victims of NIACs, and that these wars are fought with no less cruelty than IACs, it was quickly evident that a revision of the law was required. ${ }^{36}$

${ }^{31}$ ICTY, The Prosecutor v DuškoTadić, Judgment op cit para. 611. On the reasons why nonstate actors are bound, also see Haumer, S 'Non-state Armed Actors in IHL: A Demanding Relationship?' (2015) 20 Recueils de la SocieteInternationale de Droit Penal Militaire et de Droit de la Guerre at 332 and Kleffner, JK 'The Applicability of International Humanitarian Law to Organized Armed Groups’ (2011) 882 International Review of the Red Cross at 445.

${ }^{32}$ Bothe, M 'Direct Participation in Hostilities in Non-International Armed Conflict', expert paper delivered at the Second Expert Meeting on the Notion of Direct Participation in Hostilities, ICRC, The Hague (25-26 October 2004) at 5, available at https://www.icrc.org/eng/assets/files/other/2004-05-expert-paper-dph-icrc.pdf.

${ }^{33}$ Cassese op cit 120; Crawford, E 'Unequal before the Law: The Case for the Elimination of the Distinction between International and Non-international Armed Conflicts' (2007) 20 Leiden Journal of International Law at 446.

${ }^{34}$ Hill-Cawthorne, L 'Humanitarian Law, Human Rights Law and the Bifurcation of Armed Conflict' (2015) 64 International and Comparative Law Quarterly at 294.

${ }^{35}$ Cassese op cit 120; ICTY, The Prosecutor v DuškoTadić, Decision op cit para. 96.

${ }^{36}$ ICRC General Introduction to the 1987 Commentary on Protocol II (1987) at 1319; HillCawthorne op cit 294; Kress, C 'Towards Further Developing the Law of Noninternational Armed Conflicts: A Proposal for a Jus in Bello Interno and a New Jus Contra Bellum Internum' (2014) 96 International Review of the Red Cross at 30. 


\section{Protocols}

In 1970, the ICRC arranged a meeting of experts to draw up concrete proposals to be submitted to a Conference of Government Experts in 1971. The delegates agreed unanimously on the principle that Common Article 3 should be developed. Again, there was a proposal from the ICRC regarding the elimination of the distinction between IACs and NIACs through the drafting of a single international instrument. ${ }^{37}$ From a humanitarian viewpoint, the victims of armed conflict are all subject to the same suffering and should be treated in the same way. A second approach involves a number of model agreements, including all or only some of the Geneva Conventions allowing parties to implement the appropriate one, depending on the seriousness of the situation. ${ }^{38}$ The third approach, which carried majority support, provided for the drawing up of objective criteria to clarify the definition of the concept 'NIAC'. 39 These deliberations culminated in the Diplomatic Conference on the Reaffirmation and Development of IHL applicable in Armed Conflicts, which took place in Geneva in four stages from 1974 to $1977 .{ }^{40}$ The Conference led to the adoption of two Additional Protocols to the Geneva Conventions: Additional Protocol I (API), which deals with the protection of victims of IACs and Additional Protocol II (APII), which does the same for NIACs. ${ }^{41}$ The distinction between IACs and NIACs was maintained, and while API consists of 102 articles, APII contains only 28 articles.

Article 1(4) of API extends the protection of the four Geneva Conventions to "armed conflicts in which peoples are fighting against colonial domination and alien occupation and racist regimes". ${ }^{42}$ The lifting of the so-called "wars of liberation' from the category of NIACs to the domain of IACs may be regarded as innovative. ${ }^{43}$ However, the API was short-lived, as it lost most of its effect with the termination of colonialism and apartheid. ${ }^{44}$ The limitation of the extension to only certain specific types of conflict also seems rather arbitrary. ${ }^{45}$ In the words of Schindler:

\footnotetext{
${ }^{37}$ Stewart op cit 314; ICRC (1987) op cit 1327.

${ }^{38}$ Junod op cit 32 points out that six variants were drafted.

${ }^{39}$ ICRC (1987) op cit 1327.

${ }^{40}$ Crawford op cit 446.

${ }^{41}$ Hill-Cawthorne op cit 295.

${ }^{42}$ API, Art 1(4).

${ }^{43}$ Crawford op cit 446.

${ }^{44}$ Schindler, D 'International Humanitarian Law: Its Remarkable Development and its Persistent Violation' (2003) 5 Journal of the History of International Law at 173.

${ }^{45}$ Crawford op cit 447.
} 
Why should the victims of a war of secession, such as in Biafra and Bangladesh, be less protected than those in a war against colonialism or a racist regime? Of course, one can answer that it is just as wrong to treat victims of international and non-international conflicts differently. As long as humanitarian international law distinguishes between international and non-international conflicts, such injustice will be inevitable. ${ }^{46}$

On the positive side, both API and APII improved the protection of the civilian population against hostilities, by confirming the customary distinction between civilians and combatants and between civilian objects and military objectives. ${ }^{47}$ Only the latter may be lawfully attacked. Secondly, API reaffirmed and elaborated on the principles of the Hague Conventions of 1899 and 1907, concerning the methods and means of combat. ${ }^{48}$ This is important in view of the age of the Hague Conventions and of the new states, which had no part in the elaboration of the Conventions. ${ }^{49}$

The only provision applicable to NIACs before the adoption of APII was Common Article 3. APII aimed to extend the essential rules of law of armed conflict to NIACs by setting up rules regarding the conduct of hostilities and the methods and means of combat. It also aimed to define the concept 'armed conflict' more precisely through the introduction of objective criteria, thereby making it difficult for governments to deny the existence of a conflict. ${ }^{50}$ Unfortunately, the fear that the Protocol might affect state sovereignty led to the shortening of the original draft from 47 to 28 articles. Most provisions concerning the methods and means of combat were deleted. ${ }^{51}$ Like Common Article 3, Additional Protocol II also provides for the humane treatment of persons who do not participate directly or who have ceased to participate in hostilities. In addition to the acts prohibited by Common Article 3, Additional Protocol II also prohibits collective punishment as well as acts of terrorism, rape, enforced prostitution, indecent assault, slavery and pillage. ${ }^{52}$

While the extension of the humanitarian protections granted by APII is to be welcomed, the restrictive definition of the material field of application in Article 1

\footnotetext{
${ }^{46}$ Schindler, D 'The Different Types of Armed Conflicts According to the Geneva Conventions and Protocols' in Collected Courses of the Hague Academy of International Law (BrilNijhoff 1979) at 138-9.

${ }^{47}$ API, art. 48 and APII art. 13; Schindler (2003) op cit 172.

${ }^{48}$ API, art. 35-60.

${ }^{49}$ ICRC (1987) op cit.

${ }^{50}$ Junod op cit 31.

${ }^{51}$ According to the ICRC, its basic principles are still to be found in art 4 of APII; ICRC (1987) op cit.

${ }^{52}$ Art 4 of Protocol II; Crawford op cit 446.
} 
will have the effect that Protocol II will be applicable to a smaller range of internal conflicts than Article 3 common to the Conventions of 1949. Unlike Common Article 3, the Protocol does not provide for multiple non-state parties involved in armed conflict against each other, irrespective of whether there is a recognised government or not. ${ }^{53}$ Firstly, the state must be one of the parties to the conflict. Secondly, the Protocol introduces the requirement of territorial control. ${ }^{54}$ The conflict must have reached a stage where the armed group is not only in control of part of state territory but is also able to carry out sustained military operations to such an extent that they can implement the Protocol. The provisions on the activity of impartial humanitarian organisations were adopted in a less binding form than originally foreseen, and it should be kept in mind that, unlike common Article 3, which forms part of customary international law, APII will only apply if the state that is party to the internal armed conflict has ratified it.

In summary, although the Protocols represent a serious attempt to address the shortcomings of the Geneva Conventions, especially with regard to NIACs, their effect is limited. While the bulk of conflicts addressed by API do not exist anymore, APII limits the scope of NIACs to such an extent that the new rules remain inapplicable for most NIACs. ${ }^{55}$

\section{Internationalised armed conflicts}

Even as the Protocols were drawn up, a new type of NIAC emerged. ${ }^{56}$ These conflicts, which became known as 'internationalised armed conflicts' created their own unique legal challenges. Defined by Gasser as "a civil war characterised by the intervention of the armed forces of a foreign power", ${ }^{57}$ such internationalised armed conflicts contain elements of both IACs and NIACs, and can take various forms: one or more third states or an international or regional organisation could intervene -

- either in support of a state involved in an armed conflict against an organised armed group;

\footnotetext{
${ }^{53}$ Crawford op cit 448 uses the example of Angola and Somalia where dissident armed groups fought each other for control in the absence of a recognised government.

${ }^{54}$ Recalling one of the criteria for the application of the belligerency status. Oppenheim, $\mathrm{L}$ International Law: A Treatise. Vol. II: War and Neutrality (Longmans, Green and Co. 1906) at 86.

${ }^{55}$ Schindler (1979) op cit 127.

${ }^{56}$ Crawford op cit 446; Schindler (1979) op cit 127.

${ }^{57}$ Gasser, HP 'Internationalized Non-international Armed Conflicts: Case Studies of Afghanistan, Kampuchea and Lebanon' (1983) 33 (1) American University Review at 145 .
} 
- $\quad$ or in support of an organised armed group involved in an armed conflict against a state;

- $\quad$ or it could be a combination of the first two possibilities. ${ }^{58}$

According to Crawford, internationalised armed conflicts "may have started as internal conflicts but due to factors which may include third state intervention or [due] to the scope and magnitude of the conflict, have become something that transcend categorization as internal". 59

Legally, there may be three possibilities:

- $\quad$ some remain NIACs subject to the minimum standards laid down by Common Article 3 of the 1949 Geneva Conventions and Additional Protocol II;

- others become IACs subject to the full scope of the 1949 Geneva Conventions and Additional Protocol II; and

- yet others become mixed or hybrid conflicts.

Depending on the nature of the parties to the conflict, the IHL relating to NIACs applies between some of the parties (e.g. between competing armed groups or between armed groups and state parties) while the IHL relating to IACs applies to other parties (e.g. between state parties intervening at either side). ${ }^{60}$ The implication is a dual system where the rules of IAC run alongside the pre-existing and continuing NIAC. ${ }^{61}$

Against this, Stewart, with specific reference to mixed or hybrid conflicts, points out that there cannot be a "halfway house" between the laws applicable to internal armed conflicts and those that are relevant to IACs. For the purpose of applying IHL, a conflict is either wholly international or wholly non-international. ${ }^{62}$ Nothing highlights the legal uncertainty created by a divide between the law governing IAC and NIAC more than mixed conflicts. Given the differences regarding combatant status and combatant immunity, the correct classification of

\footnotetext{
${ }^{58}$ International Committee of the Red Cross 'How Does Law Protect in War?' (2017) Internationalized Internal Armed Conflict at 1, available at https://casebook.icrc.org/glossary/internationalized-internal-armed-conflict. On the intervention by international organisations such as the United Nations, see Schindler (1979) op cit 127, who mentions the example of the Congo in the period 1960-1963.

${ }^{59}$ Crawford op cit 449 ; Stewart op cit 315 describes these conflicts simply as "internal hostilities that are rendered international".

${ }^{60}$ International Committee of the Red Cross op cit 2.

${ }^{61}$ Akande, D 'Classification of Armed Conflicts: Relevant Legal Concept, in Wilmhurst, E (ed) International Law and the Classification of Conflicts (Oxford University Press 2012) at 36.

${ }^{62}$ Stewart op cit 316.
} 
armed conflicts is of critical importance to those involved as it is the measure used to judge violations of the applicable law. ${ }^{63}$ While it remains difficult to determine when internal conflict transforms into an NIAC, it can also be difficult to determine when conflict is of non-international as opposed to international character. To underline the dilemma, one only has to look at the stage when the determination is made and the parties by whom it is made. As illustrated in the Tadic case, such determinations are often made long after commencement of the conflict, in this instance, after the conflict had ceased. ${ }^{64}$ There is also no authoritative body that analyses situations of violence and categorises them publicly as being an IAC or an NIAC or not a conflict. While parties involved in the conflict may be best placed to make the determination, self-interest will often prevent states from admitting that a violent situation amounts to an armed conflict. Similarly, armed groups may have a tendency to exaggerate. ${ }^{65}$ Alternative suggestions include classification by a third state, or by an international organisation like the United Nations, the ICRC or even a new organisation or body. ${ }^{66}$

\section{Transnational armed conflicts}

The dawn of the $21^{\text {st }}$ century, especially the events of 11 September 2001, and the so-called 'war on terror', once again stimulated the IHL classification debate $^{67}$ - this time 'transnational armed conflicts' came under the spotlight. ${ }^{68}$ Underlining the geographical limitation in the definition of conflicts not of an international character in Common Article 3 of the 1949 Geneva Conventions as "occurring in the territory of one of the High Contracting Parties", the term 'transnational armed conflict' refers to cross-border or extraterritorial conflicts against armed groups. This can take numerous forms, including an internal conflict where the armed group occasionally crosses into a neighbouring country resulting in

$$
-
$$

${ }^{63}$ Bethlehem, D 'The Divide between Non-international and International Armed Conflict: Can the Gulf be Bridged?' in International Law Meeting Summary: Classification of Conflicts: The Way Forward (Chatham House 2012) at 3.

${ }^{64}$ Sivakumaran, S 'The Threshold for Non-international Armed Conflict' in International Law Meeting Summary: Classification of Conflicts: The Way Forward (Chatham House 2012) at 6.

${ }^{65}$ Ibid 6.

${ }^{66}$ Ibid 6-7.

${ }^{67}$ Shereshevsky, Y 'Politics by Other Means: The Battle over the Classification of Asymmetrical Conflicts' (2016) 49 (455) Vanderbilt Journal of Transnational Law at 475.

${ }^{68}$ Sassoli, M ‘Transnational Armed Groups and International Humanitarian Law' Program on Humanitarian Policy and Conflict Research, Occasional Paper Series (Harvard University 2006) at 1. 
- cross-border operations;

- $\quad$ conflict with an armed group primarily based in a neighbouring or in a non-neighbouring country; as well as

- conflict with multiple armed groups, which may or may not be part of the same group or network, spanning over a number of states. ${ }^{69}$

One would expect that transnational conflicts would be classified in the same way as internationalised conflicts. Providing that the thresholds with regard to intensity and organisation be met, the conflict could be either an IAC or an NIAC. If the opposing sides are states, it is an IAC, but if one or both sides are non-state armed groups, it is an NIAC. Similarly, one could have a mixed or hybrid conflict where both types of conflicts are simultaneously present. ${ }^{70}$ A prominent example of such a hybrid cross-border conflict is Israel's military operation against the Shia Lebanonbased Hezbollah group in 2006, which included heavy bombardment and destruction of state infrastructure in southern and central Lebanon. ${ }^{71}$ Nevertheless, it seems that the overwhelming majority of writers classify transnational conflicts as NIACs. ${ }^{72}$

Focussing specifically on the 'war on terror', Sassoli concludes that the conflict must be split into different components: "In some cases the law of international armed conflicts applies. In others, the law of non-international armed conflicts applies. In most situations IHL does not apply at all." ${ }^{\prime 3}$ IHL will apply in those cases where the group attacking state armed forces or state territory represents another state or are de facto acting under the direction and control of another state. ${ }^{74}$

${ }^{69}$ Lubell, N 'The Distinction between International and Non-international Armed Conflicts: Challenges for IHL?', speaking notes delivered at the International Institute of Humanitarian Law, San Remo (3-5 September 2015) at 1, available at http://www.iihl.org/wp-content/uploads/2015/11/Lubell.pdf.

${ }^{70}$ Ibid 2.

${ }^{71}$ Paulus, A \& Vashakmadze, M 'Asymmetrical War and the Notion of Armed Conflict: A Tentative Conceptualization' (2009) 91 (983) International Review of the Red Cross at 111; Lubell op cit 3 .

${ }^{72}$ Shereshevsky op cit 475, n. 87; Sivakumaran op cit 229; Paulus \& Vashakmadze op cit 1112; Akande op cit 57-67.

${ }^{73}$ Sassoli op cit, summary to the article, also see at 25 . An example may be the Boston Marathon bombers of 15 April 2013, who allegedly learned to build explosive devices from an online magazine of the al-Qaeda affiliate in Yemen.

${ }^{74}$ Ibid 4-5. Sassoli mentions Al Qaeda in Afghanistan in 2001 as a possible example that may have acted under the direction and control of a state. IHL did however apply to the conflict between the USA and the Taliban as the latter presented the de facto government of Afghanistan. More controversial is the example where a state carries out operations against a transnational group in another state's territory without the latter's consent of the latter, e.g. Israel's operations against Hizbollah in Lebanon in 2006. 
If this is not the case, the conflict should be governed by the law of NIAC. ${ }^{75}$ Just as in the case of internationalised armed conflicts, such a splitting up of reality is not entirely satisfactory.

\section{Possible solutions}

One possible solution is to extend the rules applicable in IACs to NIACs, through the application of customary law. Acknowledging that international humanitarian treaty law fails to regulate the largest portion of modern armed conflicts, i.e. NIACs, in sufficient detail, the ICRC undertook a study of the customary international law applicable to these conflicts in $2005 .{ }^{76}$ The study found that the vast majority of customary norms apply equally in both types of conflicts, thereby extending the rules applicable in IACs to NIACs. ${ }^{77}$ Although the study is regarded as a valuable contribution, it is not above criticism. According to Sassoli, the ICRC assessment of customary law is "very optimistic", ${ }^{78}$ while Shereshevsky points out that if similar norms applied equally in both types of conflict, the whole question of classification would have been redundant, which it is not. ${ }^{79}$ Bellinger and Haynes criticise the study for acknowledging the customary status of norms in AICs without sufficient evidence to support the extension of such customary norms to NIACs ${ }^{80}$ On the other hand, Sandoz observes that the study should be treated rather as a beginning than the end of a process. ${ }^{81}$ McCormack welcomes the study as a healthy development that not only created a rich source of primary customary material, but also spawned new debate on customary law itself. ${ }^{82}$ Eventually, the

${ }^{75}$ In Hamdan $v$ Ramsfeld, 548 U.S. 2006 at 67 the court held that the words "not of an international character" in common Article 3 to the Geneva Conventions bear its literal meaning; also see Corn, G \& Talbot Jensen, E 'Transnational Armed Conflict: A "Principled" Approach to the Regulation of Counter-terror Combat Operation' (2009) 42 Israel Law Review at 54.

${ }^{76}$ Henckaerts, JM 'Study on Customary International Humanitarian Law: A Contribution to the Understanding and Respect for Rule of Law in Armed Conflict' (2005) 87 (857) International Review of the Red Cross at 177-178.

${ }^{77}$ Henckaerts, JM \& Doswald-Beck, L (eds) Customary International Humanitarian Law, Volumes I \& II (Cambridge University Press 2005) at 295.

${ }^{78}$ Sassoli op cit 15.

${ }^{79}$ Shereshevsky op cit 474.

${ }^{80}$ Bellinger, JB \& Haynes, WJ 'A US Government Response to the International Committee of the Red Cross Study Customary International Humanitarian Law’ (2007) 89 (866) International Review of the Red Cross at 443-71.

${ }^{81}$ Foreword to Henckaerts \& Doswald-Beck, Volume I op cit xvii.

${ }^{82}$ McCormack, TLH 'An Australian Perspective on the ICRC Customary International Humanitarian Law Study" in Helm, AM (ed) The Law of War in the 21st Century: Weaponry and the Use of Force, Vol. 82. International Law Studies (US Naval War College 2006) at 86-8. 
ideal is that customary principles should be confirmed by case law. Even if one accepts the position of the ICRC customary IHL study, one major obstacle remains: the lack of combatant immunity or prisoner of war status in NIACs, hampering the ability of the law to mitigate suffering in armed conflicts effectively. ${ }^{83}$

Another solution is the recognition of transnational conflicts as a new category of armed conflicts governed by customary IHL. Schondorf warns against the assumption that the Geneva Conventions must cover all conflict situations, resulting in an attempt to force all conflicts into the straightjacket of being either of the interstate or intra-state variety. The mere fact that the Geneva Conventions recognises certain categories of conflict, may be useful to determine whether the Conventions, from the viewpoint of treaty law, applies to a particular conflict. However, it does not preclude the possibility that there may be additional categories of conflict not regulated by the Geneva Conventions. ${ }^{84}$ This is in line with the suggestion by Sassoli to develop a 'unique law' covering all aspects of transnational armed conflicts. To avoid losing the advances already made by IHL, "the new law should not replace the old law altogether but simply apply to a new category of transnational armed conflicts". ${ }^{85}$ Corn and Talbot Jensen suggest three essential principles of LOAC (the Law of Armed Conflict) to form the foundation of a regulatory framework covering transnational armed conflicts, to wit: military necessity, targeting and humane treatment. ${ }^{86}$

If history is the yardstick, it must be conceded that legal development takes time. While the overwhelming focus of the Geneva Conventions was still on international wars, the vast majority of armed conflicts after 1945 were noninternational or internal in nature. ${ }^{87}$ Just as the world caught up with the acceptance of the 1977 Protocols, the face of conflict changed again with the escalation in internationalised armed conflicts. While still pondering this, 9/11 took place, and transnational conflicts moved to the foreground.

There are those who revive the call for a single law of armed conflict against the background of the failure of the current regime to deal with internationalised armed conflicts. ${ }^{88}$ History illustrates that attempts by the ICRC in 1948 as well as 1971 to extend the Geneva Conventions to cover all types of armed conflicts, were met by resistance from state parties unwilling to allow intervention in what they

\footnotetext{
${ }^{83}$ Shereshevsky op cit 475.

${ }^{84}$ Schondorf, RS 'Extra-state Armed Conflicts: Is there a Need for a New Legal Regime?' (2005) 37 (1) New York University Journal of International Law and Politics at 6.

${ }^{85}$ Sassoli op cit 25.

${ }^{86}$ Corn \& Talbot Jensen op cit 79.

${ }^{87}$ ICRC (1987) op cit 1319; Hill-Cawthorne op cit 294; Kress op cit 30.

${ }^{88}$ Stewart op cit 314; Crawford op cit 457.
} 
regarded as their sovereign affairs. Other suggestions include the conclusion of a new treaty combining the rules applicable to IAC and NIAC into one substantive instrument, or new protocol. Alternatively, states may combine the respective legal frameworks applicable to AC's and NIAC's by way of unilateral declarations. ${ }^{89}$

Another suggestion is the revival of the old doctrine of belligerency. ${ }^{90}$ In terms of the doctrine insurgents could be recognised as belligerents either by the state against which they were fighting (the parent state) or by a third state. Recognition by the parent state would trigger both the full protection of the ius in bello, including prisoner of war status to insurgents, and the laws of neutrality. Recognition by a third state only led to the application of the law of neutrality. ${ }^{91}$ The classic criteria that had to be met before insurgents were recognised as belligerents were that they -

- $\quad$ had to have been in control of a certain part of the territory of the legitimate government;

- $\quad$ had to have set up a government of their own; and

- had to have fought in accordance with the laws of war. ${ }^{92}$

However, even where the circumstances for the application of the doctrine of belligerency were present, recognition remained entirely at the discretion of that particular state..$^{93}$

By the start of the 20th century, the doctrine of belligerence had fallen into disuse. ${ }^{94}$ It is claimed that the last time a government granted belligerent rights to insurgents within its territory was during the Anglo-Boer War in 1902. ${ }^{95}$ Despite this, Radin submits that the doctrine is not obsolete; it just needs to be adjusted to

\footnotetext{
${ }^{89}$ Bethlehem op cit 4.

${ }^{90}$ Kress, C., and Megret, F., (2014) "The regulation of non-international armed conflicts: Can a privilege of belligerency be envisioned in the law of non-international armed conflicts? 96 International Review of the Red Cross, pp. 29 - 66. Kress debates in favour of the privilege of belligerency while Megret points out its problematic aspects and concludes that the creation of such a privilege is not desirable.

${ }^{91}$ Hill-Cawthorne op cit 299.

${ }^{92}$ Oppenheim op cit 86.

${ }^{93}$ Hill-Cawthorne op cit 299; Crawford op cit 444.

${ }^{94}$ Solis, GD The Law of Armed Conflict: International Humanitarian Law in War (Cambridge University Press 2016) at 163. According to Moir, L The Law of Internal Armed Conflict (Cambridge University Press 2002) at 19, this was due largely to the fact that third states were anxious to protect their own shipping from the exercise of belligerent rights. Bartels, R 'Timelines, Borderlines and Conflicts: The Historical Evolution of the Legal Divide between International and Non-international Armed Conflicts' (2009) 91 (873) International Review of the Red Cross at 51.

${ }^{95}$ Moir op cit.
} 
remain relevant. ${ }^{96}$ Kretzmer ultimately argues that the test for determining the applicable legal regime should no longer be determined by formal classification. ${ }^{97}$ The real test should be whether or not a situation can be contained under a human rights regime. ${ }^{98}$ Once the law enforcement model, which underpins the human rights regime, is clearly no longer suited to deal with the scope and level of organised armed violence, the armed conflict model should apply in its entirety. ${ }^{99}$

\section{Conclusion}

Given the wide variety of NIACs and the rapidly changing international environment, the time has come to break with the positivist-formalist straightjacket of the Geneva Conventions where every armed conflict has to fit into one of two predefined categories, or even worse, into a parallel system whose nature is so difficult to determine that it may well happen after cessation of the conflict. The fact that a particular conflict falls outside the ambit of treaty law developed for circumstances that existed in the previous millennium does not imply that it falls totally outside the scope of customary international law. It is suggested that the ICRC study on customary international humanitarian law could be an invaluable asset in this regard.

${ }^{96}$ Radin, S 'The Current Relevance of the Recognition of Belligerency' in Matthee, M, Toebes, B \& Brus, M (eds) Armed Conflict and International Law: In Search of the Human Face (Asser Press 2013) at 115.

${ }^{97}$ Starting with the inquiry whether the minimum requirements for application of common Article 3 has been met.

${ }^{98}$ Which includes the possibility of derogation from some rights in an emergency.

${ }^{99}$ Kretzmer op cit 42 . For a more detailed discussion on the questions how to decide whether a situation reached the point where departure from the human rights model is necessary and the question on who must take the decision to depart, also see at 43 . 